\title{
NESTING BEHAVIOR OF THE PICAZURO PIGEON, Columba picazuro (COLUMBIDAE, AVES)
}

\author{
ONIKI, Y. and WILLIS, E. O. \\ Departamento de Zoologia, Unesp, CEP 13506-900, Rio Claro, SP, Brazil \\ Correspondence to: Yoshika Oniki, Departamento de Zoologia, Unesp, Av. 24 A, 1515, C.P. 199, CEP 13506-900, \\ Rio Claro, SP, Brazil, e-mail: ewillis@rc.unesp.br \\ Received May 19, 1999 - Accepted February 28, 2000 - Distributed November 30, 2000
}

\begin{abstract}
The Picazuro Pigeon nests in all months of the year in southeastern Brazil. Nest material is plucked from trees or ground and carried to build a frail and transparent nest of sticks where one egg is laid. Female and male alternate in incubation and brooding and do not soil the nest with feces.
\end{abstract}

Key words: nesting, behavior, Columba picazuro, Columbidae, Aves.

\section{RESUMO}

\section{Comportamento de nidificação da pomba-asa-branca, Columba picazuro (Columbidae, Aves)}

A pomba-asa-branca nidifica em todos os meses do ano no sudeste do Brasil. O material do ninho é quebrado dos ramos secos no tôpo de árvores ou pêgo no chão e levado para construir um ninho frágil e transparente onde será depositado um ovo. Fêmea e macho alternam-se na incubação e na criação do filhote e eles não sujam as bordas dos ninhos com fezes.

Palavras-chave: nidificação, comportamento, Columba picazuro, Columbidae, Aves.

\section{INTRODUCTION}

The Picazuro Pigeon or "pomba-asa-branca" (Willis \& Oniki, 1991), Columba picazuro, is common in semi-desert or cleared areas, even in cities where there are trees, in Piauí, Pernambuco and Bahia; also from Rio Grande do Sul west to Mato Grosso (Meyer de Schauensee, 1970). It invaded the state of São Paulo with deforestation, starting in 1968 (Willis \& Oniki, 1987; Alvarenga, 1990) and has been increasing in Buenos Aires since 1968 (Carman, 1975), and in Santa Catarina (Rosário, 1996). Recently it invaded the state of Rio de Janeiro (Nacinovic et al., 1988). Presently, it is one of the commonest birds in eastern Brazil.

\section{MATERIAL, STUDY AREAS, AND METHODS}

On 19 August 1993, an adult was collecting material for a nest (Nest $1=\mathrm{N} 1)$ on the campus of the Universidade Estadual Paulista (Unesp, 22 23'S, $47^{\circ} 33^{\prime} \mathrm{W}, 620 \mathrm{~m}$ elevation) in Rio Claro, SP. On 31 August 1997, at the headquarters of the Experimental Station of Luiz Antônio, SP (2134'S, 47²4'W, 650 m elevation), an adult was incubating (N2); one young hatched that day. Another nest was being built in a cedar 80 m away. On 4 September 1997, another nest (N3) had an adult incubating at the headquarters of the Zootechnical Experimental Station of Sertãozinho ( $21^{\circ} 09^{\prime} \mathrm{S}, 48^{\circ} 05^{\prime} \mathrm{W}, 520 \mathrm{~m}$ elevation).

We observed birds at three nests, for a total of 41 hours and 25 minutes, with binoculars Nikon $9 \times 23$ and Zeiss $8 \times 30$, from some $8 \mathrm{~m}$ off. We did not use blinds, for the adults did not seem disturbed by our presence.

\section{RESULTS}

\section{Nest and nesting period}

The nest is a small platform, thin enough that one can see contents from below. The nests studied 
were on the hard rachises of palm leaves (some $30-50 \mathrm{~cm}$ from the trunk). N1 and N2 were on leaves of "jerivá” (Syagrus romanzoffianum, Palmae), N3 was in a "bocaiúva", Attalea sp. (Palmae) while the other nest at Luiz Antônio in a Chamacyparys sp. (Cupressaceae). A. Z. Antunes (pers. comm.) noted a nest in construction 11 September. in the palm "rabo-de-peixe" (Caryota urens, Palmae) and another 22 August in a flamboyant tree (Delonyx regia, Caesalpiniaceae).

Thirty-one nests in construction, with egg or young, usually in dicotyledonous bushes or trees, were noted by Willis in the State of São Paulo, 2 to $30 \mathrm{~m}$ up, in all months except March and April. Britto (1950) reported nests in captivity, with one egg, from December to April. Thus, nests are known from every month of the year. All nests from Brazil had one egg or young, but Sclater \& Hudson (1889), Hartert \& Venturi (1909), Dinelli (1929), and J. Unger, fide Steinbacher (1962) reported occasional nests with two eggs. Ihering (1900), Wilson (1924), Carman (1971) and Belton (1984) noted one egg or young per nest, also Wetmore (1926) and De la Peña (1987). Apparentely the Picazuro Pigeon can have one or two eggs southward; northward, there is only one egg per nest.

\section{Nest material}

At N1, one was collecting material at 6-9 m atop a tree at 10:15 h on 19 August. Perched, he tried to break off terminal twigs with the beak, changing branch or position when unsuccessful. Once he took 5 minutes, another time 6 minutes and 22 seconds to get a twig and carry it to the nest, $50 \mathrm{~m}$ off and $5 \mathrm{~m}$ up atop the palm. August 21, at 07:48 h, an adult perched $3 \mathrm{~m}$ up and pecked off a dead twig on the first try, but let it fall. Two minutes later, he flew to the lawn below and walked about; 3 minutes later, he flew toward the nest, with a brief stop $6 \mathrm{~m}$ up. There was much construction in the morning; in 73 minutes (07:46 h-09:03 h) an adult flew 15 times to the nest with small dead twigs, which he added to the nest because the mate was not present. He usually stopped only one minute before returning to the other tree to get a twig. In several other nests, the male carried material to a presumed female sitting on the nest, as in other Columbidae.

\section{Feeding}

After dropping twigs, the pigeon often flew down, pecking and eating small seeds and bits of grit. It walked about, finally picking up a fallen twig and carrying it to the nest. This species normally feeds in open ground in open areas, far from bushes or trees. Thus, it managed to spread to humid areas of southeastern Brazil only after humans created large "desert-like" areas of open ground, previously absent except in dry regions (Willis \& Oniki, 1987). It does flee to trees when disturbed, hide in them to sing, and nest well above the ground, even nesting in dense patches of cerradão well away from borders (other than small openings where it may get twigs, but never forages). Thus, it may be unable to adapt to completely treeless fields, at least to breed.

\section{Hatching and brood care}

On 31 August, at 13:12 h, the presumed male (male Columbidae incubate at midday) at N2 had $3 / 4$ of an eggshell in the beak and let it drop. At $13: 16 \mathrm{~h}$, it chewed the rest of the shell for $30 \mathrm{se}-$ conds. The bird did not seem disturbed by the hot sun or the breeze shaking the palm leaf and nest. He brooded quietly, looking under his belly at 13:22 $\mathrm{h}$ and touching the young with his beak. He then closed his eyes as if sleeping. At 13:43 h, 13:49 h, and 14:18 h he looked about and nibbled underneath again. At 14:29 h, he regurgitated food for the young for the first time. At 14:36 he scratched his chest vigorously, near the bend of the right wing. At 14:42 h, 13 minutes after the first feeding, he fed the young again; he sat watching alertly, chest somewhat puffed out. The nest rim did not become dirty with feces, unlike Columbina talpacoti; but the leaves under the nest were spotted with white, indicating that a large pigeon in a small nest can drop feces outside, which a small one cannot.

The adult with recently hatched young behaved much as during incubation: it sat for long periods, looking under the breast now and then and moving the beak there; it closed the eyes to sleep; it could yawn or preen under the raised feathers; and it watched alertly, quiet or slowly turning the head. The adult rose now and then to regurgitate food for the young. In the heat of midday, the male kept his beak slightly open, with throat fluttering.

As in Columbidae in general, the adults alternated on the nest during incubation or brooding, not leaving the nest exposed. The female slept on the nest and the male took her place during the 
day. At N2, the changeover occurred 31 August. at $16: 56 \mathrm{~h}$; the next day, changeovers were at 07:58 $\mathrm{h}$ and 16:34 h; on 2 September, at 8:11 h.

For the changeover on 31 August, the bird on the nest sang 16:03; two others sang 16:08, one near and the other more distant, and the male sang again, then rose and poked the nestling a few times. He sat, occasionally rising to poke underneath; $16: 24 \mathrm{~h}$ he sang loudly once, stood and poked underneath, and sang again 16:26 h. 16:28 h he preened under the left wing, then sat low as a jay (Cyanocorax chrysops) passed near Oniki. At 16:34 h, he and two distant birds sang, then the male and one distant bird sang alternately; 16:36 h one bird chased another from a tree top $50 \mathrm{~m}$ off, but the male and two other birds sang. At 16:40 h he stopped, but the others continued, 16:43 h one flew to a tree $10 \mathrm{~m}$ off and gave short "u-ku" rough calls, with song $16: 45 \mathrm{~h}$ and 16:46 $\mathrm{h}$ from the male. He sang 16:49 h, 16:51 $\mathrm{h}$, and 16:52 $\mathrm{h}$ after closing the eyes a few times as if sleeping. Even though three jays called $12 \mathrm{~m}$ off, he sang again now and then. At 16:56 h, the female flew up and perched $1 \mathrm{~m}$ from the nest on another leaf of the palm. The sitting male rose 10 seconds later and walked slowly along the leaf rachis to the base of the leaf. He jumped to the next leaf and flew, while the female came to the nest leaf and walked to the nest, watching carefully about as she did so, and finally sat.

For the morning changeover, the male perched silently $8 \mathrm{~m}$ up and $8 \mathrm{~m}$ off at 7:52 h and preened his rump, belly and right wing with body feathers slightly fluffed; he flew to the nest palm and gave a faint call. The female remained immobile but answered "ku-ku!" faintly. Then, the male perched $1 \mathrm{~m}$ from nest, walked to $10 \mathrm{~cm}$ off and gave another faint note. She stood slowly but could not walk that way, so she turned and walked 10 paces carefully, flying to an ipê tree some $8 \mathrm{~m}$ away. She preened a bit with body fluffed and at 8:00 $\mathrm{h}$ flew away, while at 7:58 h, male finally sat and looked around carefully. Thus, there are sometimes exchanges of calls between the adult sitting on the nest and the arriving bird.

Before the afternoon changeover on 1 September, the male on the nest sang occasionally 16:24 h on, in response to songs from the distant cedar. He walked from the nest and flew to the ipê when the female flew to the nest leaf at 16:34 h, and she walked slowly but directly to the nest. The next morning, the female called faintly, at 08:09 $\mathrm{h}$ and $08: 11 \mathrm{~h}$, then walked off and flew after the male flew to a nearby leaf and hopped to the nest leaf. She defecated several times and preened energetically in distant tree.

\section{Young}

On 1 September, at 16:08 $\mathrm{h}$, the young had pinkish or blackish skin, with creamy to white down and pale yellow beak; it occasionally moved out under the breast of the male to receive up to four regurgitations per feeding.

\section{Reactions to other birds or people}

On 1 September, at N2, the sitting male raised both wings to vertical and watched alertly as a Chopi Blackbird (Gnorimopsar chopi) whistled in an "ipê amarelo" (Tabebuia ochracea, Bignoniaceae) $4 \mathrm{~m}$ off. It was alert 31 August when a Milvago chimachima perched atop a tree $50 \mathrm{~m}$ off, also when persons passed up to $30 \mathrm{~m}$ from the nest. When Willis passed an adult brooding a young bird in a nest $3.5 \mathrm{~m}$ up in the dense cerradão of Corumbataí, on 17 September 1993, the adult fell to the ground, flopping its wings as if injured, and flew off still pretending to fly with difficulty.

\section{DISCUSSION}

The Picazuro Pigeon, in São Paulo, nests much of the year, with one egg per nest. It pecks or knocks off twigs of a tree or bush, and can retrieve a twig on the ground to carry it to the nest. At times there is no female on the nest to receive material, which is left there without working for long. The male can sing on the nest in response to distant songs, even with nest-robber jays nearby, while male and female call faintly at nest changeovers. The nestling is fed an hour or two after hatching. Unlike small doves, the nest rim is not dirty with feces, perhaps because the bird is larger than the nest. The thin and fragile-looking nest can be used two or three times after young leave successfully (Britto, 1950; A. J. F. Cabral, pers. comm.). While the species feeds in open fields cleared by humans, it seems to need trees or scrub to sing and nest, or to hide from predators; thus it is not a bird of completely cleared fields or cities, but of partly cleared zones with occasional trees (suburban or partly cleared zones). 
Acknowledgments - We thank Drs. Antônio Carlos Zanatto (Luiz Antônio) and Leopoldo A. de Figueiredo (Sertãozinho), for permission to study birds and for hospitality. Also, thanks to Unesp for travel funds. A. Z. Antunes identified plants. Publication n. 14 of the Institute of Studies of Nature.

\section{REFERENCES}

ALVARENGA, H. M. F., 1990, Novos registros e expansões geográficas de aves no leste do Estado de São Paulo. Ararajuba, 1: 113-114.

BELTON, W., 1984, Birds of Rio Grande do Sul, Brazil. Part I. Rheidae through Furnariidae. Bull. A. M. N. H., 178: 369-636.

BRITTO, P. de M., 1950, Ninhos e ovos de algumas aves brasileiras e dados sobre a reprodução em cativeiro. Rev. Brasil. Biol., 10(3): 315-331.

CARMAN, R. L., 1971, En torno de la paloma picazuro y su postura. Hornero, 11: 126-127.

CARMAN, R. L., 1975, Apuntes sobre la distribución de la picazuro en la Provincia de Buenos Aires. Hornero, 11: 305-306.

DE LA PEÑA, M. R., 1987, Nidos y huevos de aves argentinas. Lux S. R. L., Santa Fe, 254p.

DINELLI, L., 1929, Notas biológicas sobre aves del noroeste argentino. Hornero, 4: 272-277.

HARTERT, E. \& VENTURI, S., 1909, Notes sur les oiseaux de la République Argentine. Novit. Zool., 16: 159-267.
IHERING, H. VON, 1900, Catálogo crítico-comparativo dos ninhos e ovos das aves do Brasil. Rev. Mus. Paulista, 4: 191-300.

MEYER DE SCHAUENSEE, R., 1970, A Guide to the Birds of South America. Livingston Press, Wynnewood, Pennsylvania, $470 \mathrm{p}$.

NACINOVIC, J. B., TEIXEIRA, D. M. \& LUIGI, G., 1988, Novas adendas para a avifauna do Rio de Janeiro, Brasil. Res. XV Cong. Bras. Zool., 490p.

ROSÁRIO, L. A. DO, 1996, As aves em Santa Catarina. FATMA, Florianópolis, 326p.

SCLATER, P. L. \& HUDSON, W. H., 1889, Argentine ornithology, v. 2. R. H. Porter, London.

STEINBACHER, J., 1962, Beiträge zur Kenntnis der Vögel von Paraguay. Abh. Senckenb. Naturf. Ges., 502: 1-106.

WETMORE, A., 1926, Observations on the birds of Argentina, Paraguay, Uruguay, and Chile. Bull. U. S. Nat. Museum, 133: 1-448.

WILLIS, E. O. \& ONIKI, Y., 1987, Invasion of deforested regions of São Paulo State by the Picazuro Pigeon, Columba picazuro Temminck, 1813. Ciência e Cultura, 39: 1.064-1.065.

WILLIS, E. O. \& ONIKI, Y., 1991, Nomes Gerais para as Aves Brasileiras. Gráfica da Região, Américo Brasiliense, $79 \mathrm{p}$.

WILSON, A. S., 1924, Datos biológicos sobre aves de Santa Fe. Hornero, 3: 246-248. 